\title{
Pilkada Serentak Dan Potensi Konflik di Sulawesi-Selatan
}

\author{
Ahmad Amiruddin \\ Dosen Universitas Sulawesi Barat \\ Email:ahmadamiruddin@gmail.com
}

\begin{abstract}
ABTRACT
One objective of the state is to create stability and prosperity for its people. To achieve this objective requires leader who have the capacity and integrity to accomplish the state walfare. In electoral context, one of the goals of the election is to elect a qualified leader, but the goals of fair election precisely have their own contrains, particularly conflict potentials that often occur in every election in Indonesia. In South Sulawesi, in particular, the conflict potential during the election frequently occurs in communities, which leads to friction at the elite level, so that the goals of peaceful and fair election are often far from the objectives of the public election laws.
\end{abstract}

Keywords: Conflict potentials, Public election, South Sulawesi,

\begin{abstract}
ABSTRAK
Salah satu tujuan dari Negara adalah menciptkan kestabilan dan kesejahteraan bagi masyarakat. Untuk mencapai tujuan tersebut dibutuhkan pemimpin yang memiliki kapasitas dan integritas dalam mencapai tujuan dari walfare state. Dalam konteks pemilu salah satu goals dari pemilukada adalah memimilih pemimpin yang berkualitas, namun demikian tujuan dari pemilukada yang damai adil justru memiliki kendala tersendiri terlebih potensi konflik yang sering terjadi pada setiap pelaksanaan pemilukada di Indonesia.Di Sulawesi-Selatan potensi konflik pemilukada seringkali terjadi pada masyarakat, yang membawa gesekan pada level elit sehingga tujuan dari pemilukada yang damai dan adil seringkali jauh dari tujuan dari Undang-Undang Pemilu.
\end{abstract}

Kata kunci: Pilkad Serentak, Potensi konplik, Sulawesi Selatan

\section{Pendahuluan}

Tulisan ini menjelaskan tentang potensi konflik dalam konteks pemilu, Permasalahan tersebut menyangkut sistem pemilihan bangsa ini khusunya pemilu lokal. Kemunculan UU No.32 Tahun 2004 sebagai landasan lahirnya Pilkada Langsung di berbagai daerah di Indonesia, ternyata memunculkan serangkaian konflik dalam pelaksanaannya, hal tersebut berbanding terbalik dengan tujuan sistem pemilihan langsung yang bertujuan untuk melahirkan pemimpin daerah yang lebih berkualitas (Amirudin dan Bisri, 2006:12). Konflik-konflik yang muncul cenderung berujung pada serangkaian tindakan anarkis oleh pendukung elit tertentu. Hal ini jika tidak ditangani dengan serius dikhawatirkan akan mengarah pada persoalan disintegrasi bangsa dan juga menjadi paradoks bagi bangsa ini dalam melaksanakan agenda-agenda politik di tingkat lokal.

Sebagaimana yang terjadi dalam konsepsi politik tentang keadilan yang fair dalam demokrasi merupakan cita-cita masyarakat yang diharapkan tertata dengan baik tidak pernah 
terbebas dari fakta pluralitas tentang doktrin-doktrin komprehensif. Rawls berkata,"in a wellordered society the political conception is affirmed by what we refer to reasonable offerlapping consensus". ${ }^{1}$ Setiap konsepsi politik apapun yang dipandang berguna secara publik harus selalu reasionable, walaupun konsepsi itu berbeda dan bahkan bertentangan karena berasal dari doktrin komprehensif yang berbeda-beda. Ini adalah bagian dari fakta pluralisme.

Warga negara dari suatu masyarakat yang demokratis harus menghadapi dan menerima semua ini menjadi bagian dari kehidupannya. Pertentangan antara konsepsi politik tentang keadilan yang fair sebagai dasar dari masyarakat yang tertata dengan baik dengan doktrin komprehensif (ajaran agama, pandangan filsafat, dan wasiat moral) menuntut setiap warga negara untuk bersikap bijaksana dalam memilih dan memprioritaskan keadilan yang fair di atas segala yang lain. Hal ini harus ditempuh melalui proses yang panjang. Kesepakatan dan saling pemahaman sebagai konsensus tidak gampang dicapai. Semuanya melewati offerlapping consensus yang well articulated dan highly sistematic. Konsep-konsep fundamental, prinsipprinsip dan pelbagai kebajikan politik hendaknya dipandang sebagai anggapan dasar yang perlu dipertimbangkan.

Menurut Rawls, keadilan yang fair memiliki tiga aspek penting berikut. Pertama, persyaratan-persyaratan yang berkenaan dengan keadilan dibatasi oleh struktur dasar masyarakat. Kedua, penerimaan terhadap keadilan tidak didasarkan pada pandangan komprehensif yang bersifat partikular. Ketiga, ide-ide mendasar tentang keadilan bersifat familiar dan berasal dari kultur politik publik. ${ }^{2}$ Rawls tetap berkeyakinan bahwa dalam masyarakt demokratis, fakta tentang reasionable pluralism dan offerlapping consesnsus tetap merupakan kondisi permanen. Hal ini tidak dapat dihindari. Bahkan ia menegaskan pluralisme sebagai kenyataan utama dan terpenting dalam hubungan dengan segala pertimbangan yang berkenan dengan keadilan yang fair.

Hakikat berdemokrasi pada prinsipnya terletak pada implementasi kedaulatan rakyat, dimana rakyat memegang kedaulatan sepenuhnya, melalui pemilu rakyatlah berdaulat dan berkuasa untuk menentukan bakal pemimpin masa depan. Pemilihan umum atau pemilu termasuk pemilihan kepala daerah dan wakil kepala daerah secara langsung yang santer disebut pemilukada adalah ajang penyaluran aspirasi politik masyarakat lokal untuk memilih pemimpin didaerahnya yang memiliki integritas pribadi yang baik dan jujur, sehingga pemerintahan dapat berjalan lancar.

Pemilihan umum (pemilu) menjadi salah satu parameter bagi sebuah negara yang menjalankan prinsip-prinsip demokrasi. Dalam menyelenggarakan pemilu, suatu negara demokratis seperti Indonesia, akan menyelenggarakan pemilu selama dua kali, pertama adalah untuk memilih anggota legislatif yang akan duduk sebagai wakil rakyat di parlemen, dan kedua adalah untuk memilih Presiden dan Wakil Presiden yang duduk sebagai eksekutif semacam ini

${ }^{1}$ Felix Baghi. Pluralisme, Demokrasi, dan Toleransi. Moya Zam Zam Printika, Yogyakarta: 2012, Halaman 143

${ }^{2}$ Op. Cit Halaman 144 
juga berlaku hingga di tingkat daerah, yaitu dengan memilih kepala daerah yang meliputi pemilihan Gubernur/Wakil Gubernur, pemilihan Bupati/Wakil Bupati, serta pemilihan Walikota/Wakil Walikota.

Konflik sering kali muncul dalam kehidupan masyarakat yang memiliki kekuatan yang seimbang. Apabila suatu masyarakat yang secara sosiologis dihuni oleh penduduk yang berbeda agama dan suku atau etnik, maka perbedaan itu potensial memicu munculnya konflik dan kekerasan. Kadang-kadang pihak-pihak yang berkonflik sering kali menonjolkan kepentingan pribadi dan golongan; bahwa kepedulian yang tinggi terhadap kepentingan sendiri dan kepedulian yang rendah terhadap kepentingan lain, sering kali membawa disharmonis secara sosial, ekonomi, dan politik. Dalam konteks ini, agama dan etnik tidak menjadi sumber utama dalam konflik, bahkan mungkin hanya alat untuk berkonflik, tetapi sumber utamanya adalah persoalan ketidakadilan, kemiskinan, dan kesejahteraan.

Konflik seringkali terjadi dalam proses interaksi antar-individu, individu dengan kelompok, maupun kelompok dengan kelompok yang masing-masing disebabkan oleh perbedaan baik dalam latar belakang interaksi, kemampuan berinteraksi, maupun tujuan berinteraksi. Tidak terkecuali konflik juga terjadi pada masyarakat Indonesia yang mempunyai latar belakang politik, etnis, dan agama yang berbeda. Dari latar belakang yang beragam ini, corak konflik di Indonesiapun juga beragam.

Dalam proses pelaksanaannya, pemilihan kepala daerah (pilkada) langsung ternyata seringkali menyebabkan sejumlah persoalan terkait proses pelaksanaannya yang dinilai cenderung menghamburkan dana rakyat termasuk dugaan money politic, serta tidak jarang hasil pilkada langsung itu direspon secara negatif sehingga berbuntut kerusuhan dan kekerasan.

Konflik pasca pilkada yang berbuntut aksi kekerasan yang menjurus kerusuhan dapat dilihat pada kerusuhan pasca pemilihan bupati di Kabupaten Tuban Jawa Timur pada tahun 2006. Kerusuhan di Tuban itu mengakibatkan sejumlah sarana pemerintah dan swasta hangus terbakar akibat aksi massa. Sebelumnya terjadi polemik hukum yang juga berimbas pada aksi massa terkait hasil Pemilihan Walikota Kota Depok. Pada konteks pemilihan Gubernur, persoalan serta konflik pasca pemilihan kepala daerah (pilkada) langsung juga tidak bisa dihindari. Ini terlihat pada pemilihan gubernur (Pilgub) Maluku Utara yang berujung konflik dan persoalan hukum yang berkepanjangan. Kondisi yang sama terjadi pasca Pemilihan Gubernur Sulawesi Selatan tahun 2009 yang membuat kondisi provinsi itu baik bidang keamanan dan stabilitas politik memanas. ${ }^{3}$

Beberapa polemik konflik di Sulawesi Selatan selain konflik pasca Pemilihan Gubernur Sulawesi Selatan tahun 2009, juga terdapat konflik pada sejumlah daerah. Misalnya, konflik yang terjadi di Kabupaten Pangkep tahun 2005 dimana massa pada saat itu menyegel kantor KPU. Hal serupa juga terjadi di Kabupaten Toraja dan Kabupaten Soppeng tahun 2008. Terajadi amuk massa yang berdampak pada penyegelan kantor KPU dan rusaknya kertas suara yan di

${ }^{3}$ Lebih jauh terkait konflik pasca pilkada langsung bisa dilihat pada Kacung Marijan, Demokratisasi di Daerah, Pelajaran Langsung dari Pilkada Langsung, Pustaka Eureka,Surabaya, 2006. Hal 63-67 
bakar massa. Hal ini dipicu oleh adanya kecurigaan massa terhadap penyelenggara pemilu yang tidak terbuka pada msyarakat dalam penghitungan suara.

Dalam konteks Negara demokrasi, Maswadi Rauf menyatakan bahwa wajar apabila demokrasi dipenuhi oleh konflik karena setiap orang atau kelompok mempunyai kepentingan dan pendapat masing-masing yang bukan saja berbeda tetapi bahkan dapat bertentangan satu sama lain. ${ }^{4}$ Kebebasan untuk mengkritik atau menentang pihak lain yang mempunyai pendapat dan kepentingan yang berbeda atau berlawanan yang membuat konflik kepentingan pesat didalam masyarakat. Untuk konteks Indonesia yang berada dalam transisi demokrasi, munculnya konflik yang lahir sebagai akibat dari perbedaan kepentingan mungkin dapat dipahami sebagai proses menuju konsolidasi demokrasi dan pelembagaan demokrasi. Untuk mengatasi dampak negatif yang dapat dihasilkan oleh konflik, demokrasi mengharuskan adanya kemampuan warga masyarakat dan pemerintah untuk menyelesaikan konflik sebelum konflik menjadi intensif dan ekstensif. Demokrasi mengharuskan adanya keterampilan untuk menyelesaikan konflik sebagai jalan keluar dari konflik yang terjadi.

Pada platform inilah proses demokratisasi akan menemukan "ruang gerak"-nya secara dinamis, kendatipun tak ada yang bisa menjamin sepenuhnya karena berbagai realitas dan fenomena sosial, budaya, ekonomi, dan politik rakyat saling terkait dan saling mempengaruhi. Pada tataran ini, pilkada secara langsung akan menjadi satu momentum berharga bagi rakyat dalam memilih pemimpinnya dan sekaligus tantangan dan ujian bagi proses pendidikan politik rakyat Indonesia. Hal yang perlu diingat, dalam proses demokratisasi ini terdapat kelemahan, di mana kebebasan dan pengabaian rakyat untuk memilih secara bebas, rasional, terbuka dan reflektif akan berdampak pada munculnya apatisme politik rakyat yang lebih membahayakan bentuk pemerintahan konstitusional.

Dalam masyarakat majemuk yang penduduk terdiri dari bebagai suku, ras, agama, kelompok dan golongan, masalah pengintegrasian kelompok-kelompok tersebut merupakan masalah yang rumit. Dalam kehidupan berbangsa dan bernegara, skema kemajemukan tidak jarang menjadi potensi konflik dalam masyarakat, hal ini memungkinkan juga terjadinya konflik pada pilkada serentak di Sulawesi-Selatan nantinya.

Potensi konflik biasanya dapat dengan mudah tumbuh dan berkembang melalui aspekaspek primordial, seperti etnis, agama, ataupun kebudayaan. Dalam kondisi masyarakat yang majemuk, potensi terjadinya konflik pada pilkada serentak nantinya menjadi menarik untuk dicermati. Sebab, potensi konflik yang berasal dari aspek primordial cenderung sulit untuk dihilangkan dari keberagaman kondisi sosial di Sulawesi-Selatan.

\section{Pembilahan Sosial di Sulawesi-Selatan}

${ }^{4}$ Jayadi Nas, Konflik Elite di Sulawesi Selatan; Analisis Pemerintahan dan Politik Lokal. Lembaga Penerbitan Universitas Hasanuddin, Makassar, 2007. Hal 30 
Teori pembilahan sosial adalah konsep yang digunakan dalam sosiologi dan ilmu politik untuk menjelajahi bagaimana masyarakat dibagi menjadi kelompok. Pembilahan sosial menurut Lipset dan Rokkan, untuk pengelompokan sosial yang akan disebut sebagai pembilahan sosial, harus memenuhi tiga syarat. Pertama, harus ada divisi dalam masyarakat berdasarkan faktor demografi atau sosial ekonomi tertentu. Contoh faktor tersebut adalah kelas, pekerjaan, kelompok etnis dan agama yang dianut. Karakteristik ini untuk memisahkan mereka dari anggota masyarakat lainnya. Kedua, orang pada satu sisi kesenjangan sosial harus menyadari bahwa karakteristik obligasi mereka bersama-sama, dan mereka harus menunjukkan kemauan untuk bertindak mempromosikan kepentingan yang terkait dengan identitas sosial mereka. ${ }^{5}$

Dengan adanya basis sosial yang berbeda di tengah masyarakat memungkinkan menjadi salah satu faktor penyebab konflik ketika hal tersebut dijadikan isu oleh tim pemenangan elit untuk meraih dukungan suara. Sebab jika pembilahan sosial ini dalam titik yang ekstrim bisa memicu ke arah konflik sosial yang besar. Pertama, pada basis tradisional yang terdiri dari unsur etnik, budaya, agama dan regional. Etnik mencakupi segala aspek kebudayaan. Misalnya, di Sulawesi-Selatan terdapat beragam etnik, ada etnik Bugis, Makassar, Mandar, Tionghoa dan lain sebagainya. Keragaman etnik, budaya dan agama ini menjadi sebuah isu yang menarik dalam Pemilukada.

Agama sendiri dianggap tidak terlalu menjadi potensi yang besar dalam memicu terjadinya konflik pemilukada selama ini. Persoalan kewilayahan juga kadangkala muncul menjadi isu yang dikemas oleh para kandidat dan tim untuk menarik massa, pembilahan yang terjadi pada basis tradisional ini melibatkan massa dengan derajat militansi yang cukup tinggi, maka ikatan yang terbentuk cenderung memiliki ikatan emosional yang terjalin di antara massa dan elit politik itu sendiri.

Hal ini terjadi karena adanya ikatan emosional yang terjadi karena adanya ikatan kekerabatan antara kelompok, etnis, atapun lapisan masyarakat tertentu dan calon yang ingin dipilihnya. Dengan adanya ikatan emosional yang kuat, kecenderungan untuk membela calon walikota pilihannya akan semakin besar maksudnya tingkat militansi massa pendukung akan besar. Sehingga berpotensi menimbulkan konflik pada pemilukada serentak di Sulawesi-Selatan. Selain dari basis tradisional, juga sudah muncul pola-pola modern seperti pembilahan kelas atas, menengah dan bawah apakah sudah hadir di Sulawesi-Selatan. Yang dimaksud dengan pembilahan sosial yang moderen adalah pembilahan yang mengikuti pola masyarakat yang industrial yang terbagi karena adanya penguasaan properti dan pembagian kerja.

Pembilahan sosial pada basis tradisional dikelompokkan kedalam kelompok dengan tingkat militansi yang tinggi sedangkan pembilahan sosial pada basis pemilih yang modern dikelompokkan kedalam bagian dengan tingkat militansi yang rendah.

Pembilahan sosial yang dapat memicu terjadi konflik Pemilukada :

${ }^{5}$ Seymour Martin Lipset, Political Man: Basis Sosial Tentang Politik. Pustaka Pelajar.Yogyakarta: 2007. 


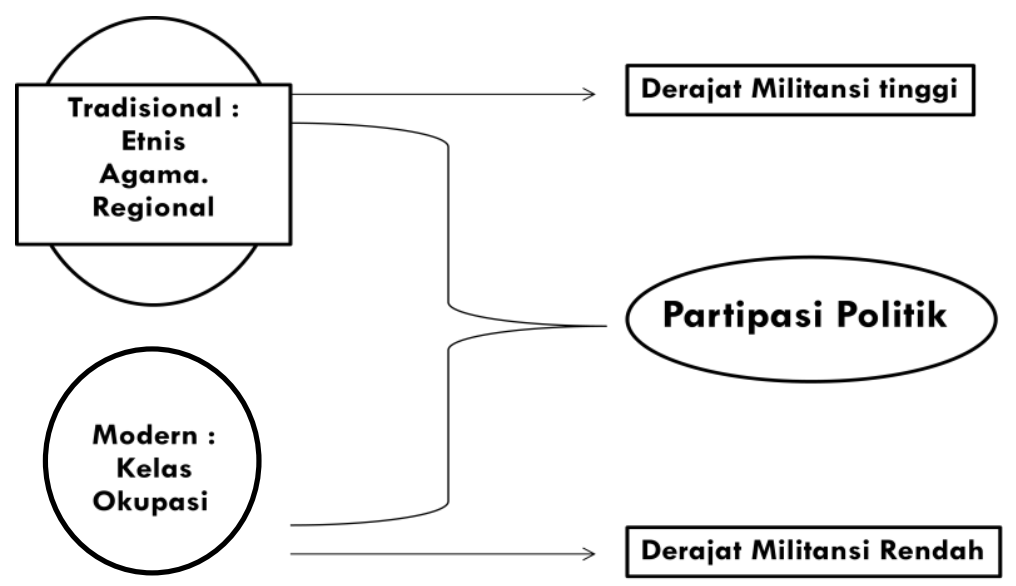

Skema 1.2 Pola Hubungan Politik

\section{Pola Hubungan Politik}

Pola hubungan politik yang terbentuk antara elit dengan massa juga menjadi sangat menarik dimana ada tiga hubungan politik yang bisa dibangun oleh para kandidat dengan pemilihnya. Masing-masing tipe hubungan politik ini memiliki keunikan tersendiri dan juga memiliki potensi menjadi pemicu konflik mulai dari tingkat yang paling rendah ketingkat yang paling tinggi.

Skema 1.3 Pola Hubungan Politik

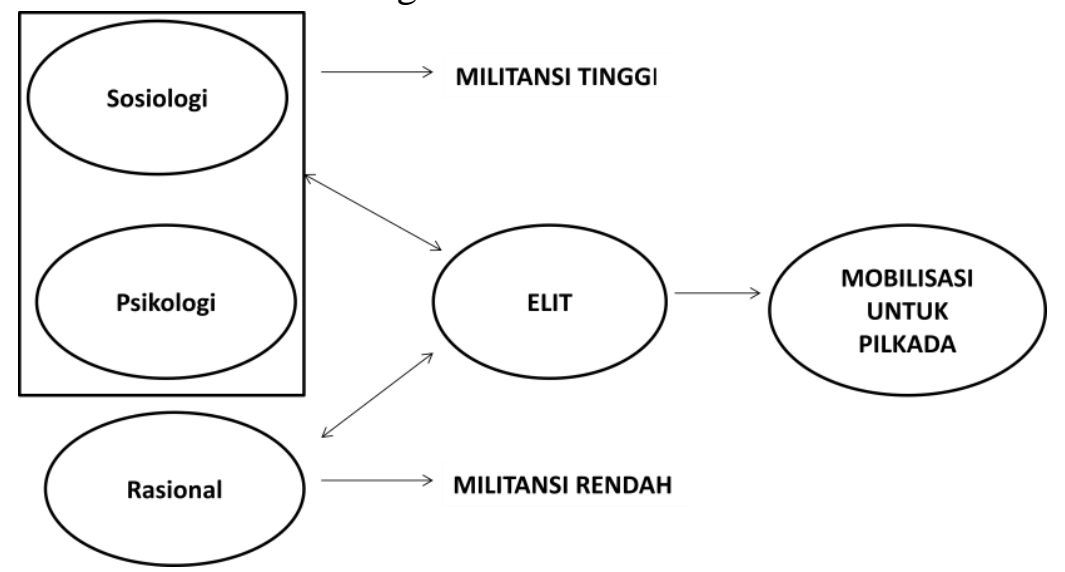

\section{a. Hubungan Sosiologis}

Dalam melakukan pendekatan dengan massa, para kandidat atau partai politik yang bertarung dalam pilkada memiliki kecenderungan untuk membangun hubungan yang kuat dengan basis massa. Dasar pembentukan hubungan politik ini juga bervariasi. Ada kandidat yang cenderung untuk membangun hubungan politik dengan pemilihnya berdasarkan basis sosial yang ada dengan memanfaatkan hubungan-hubungan sosiaologis, seperti kekerabatan, etnis, kelompok, pertaemanan, komunitas, kedaerahan dan lain sebagainya.

Hubungan yang dibentuk dengan basis sosiologis ini cenderung melahirkan hubungan politik yang kuat. Ini dikarenakan ikatan sosial yang kuat dalam keluarga, komunitas, kelompok, 
etnis, dan lainnya ditransfer menjadi hubungan politik. Hubungan politik ini didasari pada karakter ikatan yang bersifat emosional sehingga ketika ikatan yang kuat ini dimanfaatkan untuk memobilisasi massa, maka kumpulan massa yang dimobilisasi tersebut cenderung untuk militan. Tingginya tingkat militansi dalam hubungan ini akibat dari hubungan emosional yang kuat, dan hal ini memiliki potensi yang besar untuk menjelma menjadi radikalisme jika diarahkan atau diprovokasi untuk hal-hal yang negatif. Dalam hal ini, hubungan politik ini bisa saja dimanfaatkan untuk mendorong massa melakukan tindakan-tindakan anarkis, seperti perusakan, penyerangan, dan lain sebagainya.

Dalam konteks pemilu seringkalai ditemukan beberapa kandidat membangun hubungan politik dengan memanfaatkan ikatan kekerabatan, komunitas-komunitas ataupun kelompokkelompok masyarakat yang ada. Selain itu, isu-isu yang digunakan kebanyakan isu-isu yang bersifat sosiologis. Sehingga hal ini bisa mendorong masyarakat untuk memaknai hubungan yang coba dibangun oleh kandidat secara sosiologis. Ini tentu saja akan mendorong terbentuknya hubungan politik yang dilandasi oleh ikatan emosional yang mengambil basis pada komunitas, kelompok, lapisan msyarakat atau etnis tertentu. Jika hal ini dibiarkan, maka para kandidat nantinya akan banyak memiliki pendukung-pendukung yang militan. Sehingga sangat potensial berkembang menjadi massa-massa yang radikal.

b. Hubungan Psikologis

Pada pendekatan ini, calon melakukan pendekatan kepada masyarakat berdasarkan polapola ikatan emosional yang kuat, misalnya mendekati individu berdasarkan kesamaan kegemaran, atau kadang-kadang calon kandidat atau partai menciptakan istilah yang secara familiar banyak disukai orang dan kemudian hal itu secara perlahan melakat sebagai identitas baru, misalnya istilah punggawa yang dipopulerkan oleh pasangan calon gubernur Sulawesi Selatan Ichsan Yasin Limpo dan Andi Mudzakkar. Istilah punggawa menjadi bahasa keseharian dan kemudian melekat di benak masyarakat dan tidak menutup kemungkinan kemudian mempengaruhi pilihannya.

Hal lain yang biasa mempengaruhi pilihan masyarakat adalah faktor ketokohan calon yang memiliki kharisma, misalnya ketokohan Qahhar Mudzakkar di Sulawesi Selatan masih memiliki pengaruh besar bagi sebagian orang sehingga ketika anaknya Aziz Qahhar mencalonkan diri maka kehadirannya sangat diperhitungkan mendapatkan dukungan yang besar, terbukti bahwa dengan alasan itu Nurdin Halid memilih Aziz Qahhar mendampinginya maju di Pemilhan Gubernur Sulawesi Selatan.

\section{c. Hubungan Rasional.}

Pada hubungan rasional massa cenderung memilih kandidat yang memberi tawaran visi misi yang dapat meyakinkan mereka akan terwakilinya keinginan dan segala bentuk penyelesaian masalah sosial yang dihadapi dari calon kandidat yang mereka dukung.

Pendekatan ini menekankan pada variabel lain yang menetukan atau ikut menentukan dalam mempengaruhi hubungan politik. Ada faktor situasional yang ikut berperan dalam mempengaruhi hubungan politik seseorang. Dengan begitu para pemilih bukan hanya pasif tetapi juga aktif dan bukan hanya terbelenggu oleh karakteristik sosiologis dan psikologis, tetapi juga 
bebas bertindak. Faktor-faktor situasional itu dapat berupa isu-isu politik atau kandidat yang dicalonkan. Dengan demikian penjelasan-penjelasan hubungan politik yang telah ada tidak harus permanen, seperti karakteristik psikologis dan identifikasin partai, tetapi berubah-ubah sesuai dengan waktu dan peristiwa-peristiwa politik tertentu.

Dengan begitu isu-isu politik menjadi pertimbangan yang penting. Para pemilih akan menentukan pilihannya berdasarkan penilaiannya terhadap isu-isu politik dan kandidat yang diajukan. Artinya, para pemilih dapat menentukan pilihannya berdasarkan pertimbanganpertimbangan rasional, dan hubungan politik bukan hanya ditentukan oleh faktor karakteristik sosial dan identifikasin partai.

Terbangunnya hubungan politik melalui pendekatan rasional disebabkan oleh adanya orientasi terhadap isu yang dibangun oleh calon atau partai politik yang dianggap berkualitas, membawa informasi yang dibutuhkan, serta segala identitas yang melekat pada diri calon atau partai politik yang dianggap sesuai dengan harapan masyarakat.

Ikatan emosional yang terbangun juga dapat mempengaruhi tingkat militansi dukungan massa terhadap calon kandidat walikota. Dalam hal ini bisa kita ambil contoh dari aspek hubungan politik yang dibangun atas dasar pendekatan sosiologis dan pendekatan psikologis. Jika dilihat dari aspek lainnya yakni dari pola hubungan politik melalui pendekatan rasional, maka pola hubungan yang terjalin adalah hubungan yang berdasarkan pada pendekatan yang dapat diterima oleh akal serta dapat dikaji secara ilmiah. Melalui pendekatan ini calon dituntut untuk bisa meyakinkan masyarakat melalui visi-misi yang realistis. Dalam pendekatan ini derajat militansi masyarakat tergolong rendah karena masyarakat lebih mengedepankan hasil pemikiran daripada kedekatan emosional.

\section{Karakteristik Pemilih}

Karakteristik pemilih di Sulawesi-Selatan berdasarkan tingkat militansinya (Lihat Skema 1.4 Karakteristik Pemilih). ${ }^{6}$

"Anthony Down, An Economic Theory of Democracy", 1957. 


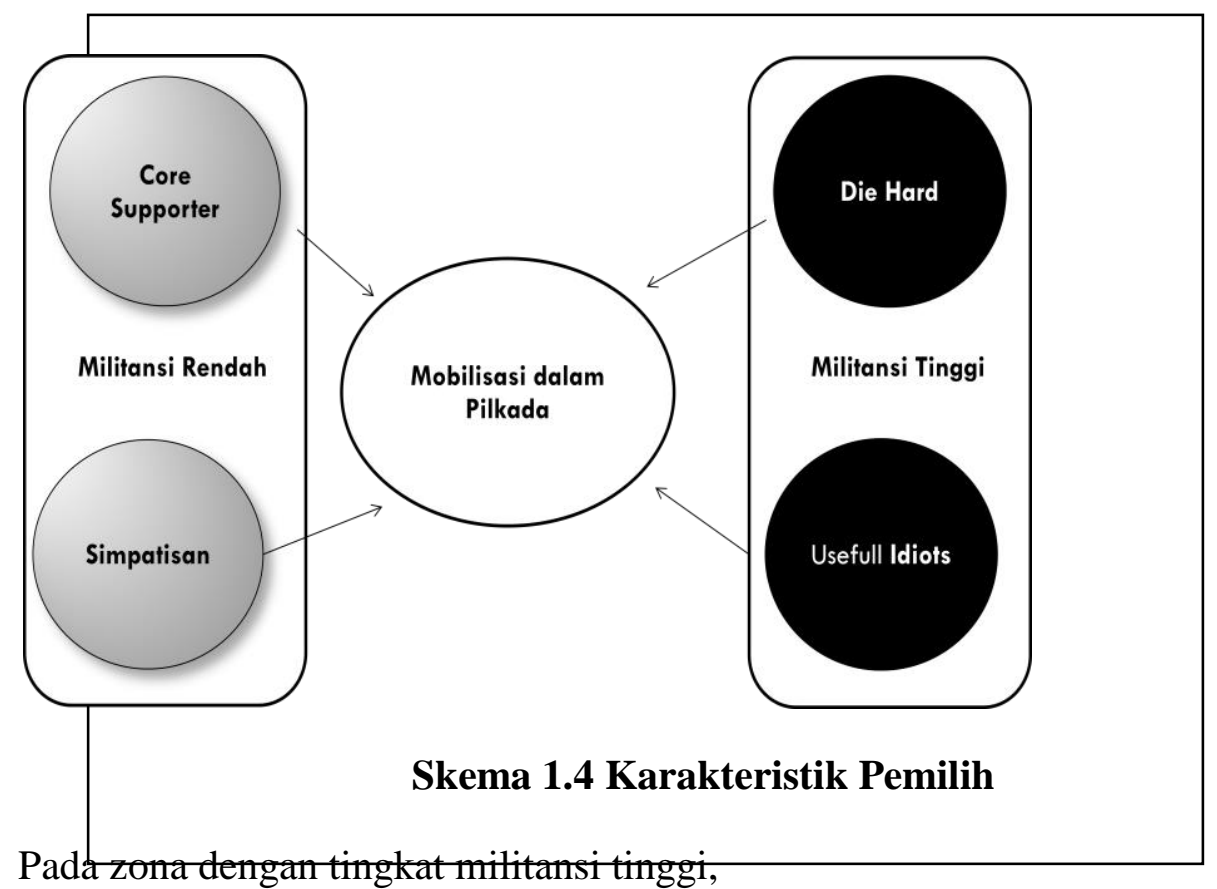

\section{Die Hard Supporter}

Kelompok pemilih Die Hard Supporter ini dalam istilah yang lain dikenal juga dengan sebutan True Believers, yang maksud adalah mereka yang rela berkorban baik itu moril dan materi, bahkan rela mati demi keyakinannya. Menurut data yang temukan dilapangan, kelompok ini yang menjadi penyumbang terbesar konflik. Karena mereka sangat radikal terhadap sebuah pilihan, contoh sederhanya adalah seperti supporter sepak bola. Bagaimana bentuk radikalisme pendukung pada kelompok Die Hard Supporter ini,

\section{Usefull Idiots}

Kelompok ini adalah mereka yang tidak punya kepentingan politik tapi mereka mudah di manfaatkan karena mereka adalah orang-orang pragmatis. Kadang-kadang ada tenaga-tenaga bayaran yang memang sengaja di bayar untuk ikut berkampanye misalnya dengan diberikan baju kaos, diberikan uang, dan kadangkala karena mereka tidak tahu dan tidak mempunyai koordinasi yang baik dan hal yang bisa memicu munculnya pergesekan karena pada kelompok ini cenderung mudah di mobilisasi.

Hubungan politik yang didasari oleh ikatan emosional akan mengarahkan massa pada tingkat militansi yang tinggi. jika massa dimobilisasi ke arah yang negatif kecenderungan untuk menjadi radikal dapat terjadi dan konflikpun tidak dapat terhindarkan lagi.

\section{Core Supporter}

Kelompok ini adalah orang yang memang mempunyai kepentingan politik, berafiliasi pada parpol tertentu, dan kelompok ini adalah mereka yang mengetahui kondisi-kondisi yang terjadi di dalam partai misalnya mereka yang menjadi tim pemenangan maupun orang-orang dalam partai.

Pendukung yang tergolong dalam kelompok Core Supporter adalah mereka yang mempunyai hubungan politik karena adanya ikatan kelembagaan atau organisasi. Pendukung yang tergabung dalam kelompok Core Supporter cenderung memilih calon karena adanya visi 
misi atau tujuan yang sama dengan calon yang dia dukung oleh masyarakat. Ikatan yang seperti ini cenderung memilih pasangan karena alasan tertentu misalnya karena alasan kesamamaan visi dan misi dengan calon yang didukungnya. Alasan yang dikemukakan tersebut dikarenakan adanya ikatan psikologis dan kecenderungan untuk dimobilisasi ke arah negatif kecil, sehingga kecil juga kemungkinan untuk mengarah terjadinya konflik pada pemilukada.

\section{Simpatisan}

Kelompok ini adalah mereka yang hanya memilih berdasarkan informasi yang mereka terima. Orang yang berada pada kelompok ini adalah mereka yang tidak mempunyai ikatan pada organisasi manapun, partai politik manapun, tidak memiliki ikatan emosional dan organisasional terhadap kandidat yang ada. Kelompok ini hanya bereaksi berdasarkan rasionalisasi dari apa yang ditawarkan oleh kandidat dan tim suksesnya.

Keempat jenis kelompok masyarakat inilah yang membentuk struktur pendukung kandidat yang akan bertarung dalam pilkada. Jika kelompok yang berada pada zona dengan tingkat militansi tinggi lebih besar pemanfaatannya dalam kegiatan politik dalam hal ini dalam Pilkada serentak nantinya maka ini rawan memicu potensi konflik yang lebih besar. Ini dikarenakan orang-orang dalam kelompok Die Hard Supporter dan Usefull Idiot adalah orangorang militan, ketika mereka di mobilisasi dalam pilkada, bisa menjadi pemicu terjadinya konflik dalam pilkada. Berbeda dengan kelompok pemilih dengan tingkat militansi rendah yakni Core Supporter dan Simpatisan, pada kelompok ini pemilihnya lebih cenderung mengarah ke tingkat pemilih rasional sehingga pada kelompok pemilih ini tingkat militansi rendah sehingga ketika mereka dimobilisasi untuk berbagai kegiatan politik, mereka cenderung tidak radikal.

\section{Peran Negara dalam Penyelesaian Konflik Pilkada.}

Pelaksanaan UU No. 32 Tahun 2004 dalam mengawal Pilkada damai,jujur dan adil di berbagai daerah di Sulawesi-selatan, menaruh perhatian serius bahwa negara tidak sepenuhnya membuat regulasi tentang rule aturan yang dapat menghindarkan pelaksanaan Pilkada serentak dari berbagai macam konflik kepentingan. Berbagai macam aturan yang dibuat di luar aturan formal sebelum proses pelaksanaan Pilkada dilangsungkan, menjadi salah satu indikator ketidakpercayaan elit terhadap aturan yang ada untuk meminimalisir terjadinya konflik di daerah yang ditimbul oleh pilkada. Namun demikian, pada hakikatnya justru akan menimbulkan potensi konflik yang lain, di mana kesepakatan yang telah dibuat justru mendistorsi aturan formal. Kecenderungan ini justru membuat posisi Negara seolah tidak berdaya dalam bertindak sebagai pengawas dan pelaksana, sampai bertindak sebagai penyelesai konflik yang

terjadi.

Negara mempunyai peran yang sangat penting dalam menyelesaikan konflik Pilkada yang terjadi di daerah. Konflik Pilkada adalah sebuah bentuk konflik kepentingan dalam perebutan kekuasaan menjadi sebagai pelajaran dalam pembangunan demokrasi bagi bangsa 
ini. Berbagai konflik dan gesekan elit yang seringkali muncul dalam Pilkada mengindikasikan bahwa dinamika politik yang terjadi pada setiap daerah sangat variatif .

Konflik Pilkada yang terjadi menimbulkan dampat terhadap disintegrasi bangsa menjadikan tujuan demokrasi untuk menciptakan banyak pemimpin-pemimpin yang berintegritas (a democracy of leaders) di daerah menjadi tidak terbukti. Bahkan seringkali konflik yang terjadi bisa menciptakan ketakutan terhadap sistem pemilihan langsung sendiri, tujuan perubahan yang diharapkan tidak terwujud. Hal ini jika tidak dikelola dan disikapi dengan baik, permasalahan yang sering terjadi dalam pemilukada dikhawatirkan akan menghambat agenda demokratisasi serta menambah persoalan baru dalam tatanan politik lokal di Indonesia.

Terjadinya berbagai macam konflik di daerah dalam pemilukada, bukan berarti tidak memiliki penyelesaian. Setiap masalah ada jalan keluarnya, setiap konflik ada solusinya, dan setiap krisis mengandung peluang (Yudhoyono dalam Djalal, 2008: 18), dengan demikian Negara perlu melihat peluang dalam menjamin perdamaian dalam pelaksaan pemilukada. Kejelian negara melihat peluang dan memilih strategi resolusi konflik yang dapat digunakan, akan menentukan keefektifan kebijakan yang dipilih dalam mempengaruhi penyelesaian konflik yang diharapakan berlangsung secara damai.Dengan demikian Negara harus kuat, Negara memiliki peran penting dalam melakukan resolusi konflik untuk menjamin ketertiban dan stabilitas masyarakatnya (Anderson dalam Kaho dan Haryanto, Tanpa Tahun: 8-9), karena dalam perspektif konflik negara memiliki posisi dan kewenangan dalam membuat keputusan serta melaksanakan keputusan secara sah sebagai penyelesai konflik. Negara juga memiliki kewenangan untuk mengatur dan masyarakat harus tunduk dan patuh dengan Negara.

Bagi Nodlinger, Kresner dan Skropcol (dalam Rozy, 2006: 12-13), negara diartikan sebagai individu, lembaga ataupun yang menduduki jabatan memiliki kewenangan membuat dan melaksanakan keputusan mengikat semua pihak yang ada dalam wilayah tertentu. Dari perspektif Nodlinger tentang Negara, dapat dipahami bagaimana Pemerintah Kabupaten dan institusi terkait lainnya (seperti KPU, Bawaslu dan lembaga Kepolisian) adalah merupakan elemen negara yang memiliki peran penting dalam menyelesaikan suatu konflik yang terjadi dalam pelaksanaan Pemilukada serentak diberbagai daerah. Keterlibatan elemen negara dalam proses penyelesaian konflik sendiri mengindikasikan kenetralan dan memadukan gerak langkah seluruh lembaga terkait berbasis perdamaian menjadi sangat dibutuhkan, selain juga menjaga kredibilitas negara sebagai penyelesai yang baik.

Negara mempunyai peran yang sangat penting dalam merumuskan dan menghasilkan kebijakan resolusi konflik secara partisipatif, komperhensif, dan tidak diskriminatif. Kegagalan negara dalam pelakaan pilkada dan pengelolaan konflik yang terjadi, justru akan mempengaruhi kualitas Pilkada dan mempengaruhi kehidupan sosial masyarakat, dan berdampak pada keberlangsungan politik daerah setempat. Peran negara dalam melihat peluang serta memilih strategi penyelesaian yang tepat, merupakan sebuah solusi yang perlu 
diperhatikan untuk menciptakan perdamaian, di balik posisi penting negara sebagai penyelesai konflik Pilkada yang terjadi di Indonesia.

\section{Kesimpulan}

Jika ditinjau dari aspek pembilahan sosial di Sulawesi yakni dari basis tradisional dan modern, maka penulis menyimpulkan yang paling berpotensi menimbulkan konflik pada pilkada serentak nantinya adalah massa pendukung dari basis tradisional. Hal ini dikarenakan, ikatan emosional yang terjalin lebih kuat, sehingga lebih mudah untuk dimobilisasi. Dari ketiga pola hubungan politik yang telah penulis jelaskan, penulis berkesimpulan bahwa pola hubungan yang berpotensi menimbulkan konflik pemilukada adalah pola hubungan sosiologisdan psikologi. Pola hubungan sosiologi paling berpotensi menimbulkan konflik. Sebab, hubungan yang dibentuk cenderung melahirkan hubungan politik yang kuat. Ini dikarenakan ikatan sosial yang kuat dalam keluarga, komunitas, kelompok, etnis, dan lainnya ditransfer menjadi yang bersifat emosional sehingga ketika ikatan yang kuat ini dimanfaatkan untuk memobilisasi massa menjadi militan.

Karakter pemilih yang menjadi faktor yang berpotensi menimbulkan konflik pemilukada adalah kelompok yang tergolong pada tingkat militansi tinggi yakni kelompok Die Hard Supporter dan usefull idiots. Kedua kelompok ini menjadi sumber konflik terbesar. Utamanya dari kelompok Die Hard Supporter. Karena, kelompok ini cenderung akan menjadi kelompok yang radikal dan bisa dimanfaatkan untuk mendorong massa melakukan tindakan-tindakan anarkis, seperti perusakan, penyerangan, dan lain sebagainya

Faktor intitusional seperti penyelenggara pemilu bisa menjadi sumber terjadinya konflik pada pemilukada ketika tidak terjadi transparansi informasi kepada masyarakat. Masyarakat tidak mungkin melakukan aksi kekerasan jika apa yang ingin diketahuinya bisa didapatkan. begitupun dengan Aparat Kemananan sebagai sebuah instansi yang bertugas mengamankan jalannya pemilu, aparat keamanan dalam hal ini pihak kepolisian yang bertugas dilapangan harus tanggap pada situasi dan kondisi yang terjadi, sehingga jika terjadi konflik maka konflik itu dapat diminimalisir dan tidak mengalamai eskalasi konflik.

Konflik yang terjadi pada internal partai politik ini yaitu berawal ketika penjaringan calon, dalam hal ini pada saat penetapan nomor urut calon. Terjadinya konflik internal pada partai politik jika tidak segera diselesaikan di intern partai tersebut maka akan memberikan pengaruh yang besar pada terjadinya konflik yang berujung kekerasan yang dilakukan oleh para pendukung dari masing-masing calon.

\section{Daftar Pustaka}

[1] Baghi, Felix. 2012. Pluralisme, Demokrasi, dan Toleransi. Yogyakarta: Moya Zam Zam Printika. 
[2] Budiardjo, Miriam , 2008. Dasar-Dasar Ilmu Politik (Edisi revisi), PT. Gramedia Pustaka Utama, Jakarta.

[3] Bungin, Burhan, 2001. Metodologi Penelitian Kualitatif. Rajawali Pers, Jakarta.

[4] Down, Anthony. An Economic Theory of Democracy”, 1957.

[5] Duverger, Maurice, 1982. Sosiologi Politik, Rajawali, Jakarta

[6] Efriza, 2012. Political Explore. Bandung: CV. Alfabeta

[7] Kartono, Kartini. 1999. Patologi Sosial. Jakarta: CV. Rajawali

[8] Lexy, J.Moleong, 2008. Metodologi Penelitian Kualitatif (edisi revisi), PT. Remaja Rosdakarya, Bandung.

[9] Lipset, Marti n, Seymour. 2007. Political Man: Basis Sosial Tentang Politik. Yogyakarta : Pustaka Pelajar

[10] Marijan, Kacung. 2006. Demokratisasi di Daerah, Pelajaran Langsung dari Pilkada Langsung. Surabaya: Pustaka Eureka

[11] Nas, Jayadi, 2007. Konflik Elite di Sulawesi Selatan; Analisis Pemerintahan dan Politik Lokal. Lembaga Penerbitan Universitas Hasanuddin, Makassar

[12] Nasikun, DR . 2011. Sistem Sosial Indonesia. Jakarta: PT Raja Grafindo Persada

[13] Newcomb, Theodore M, dkk. 1978. Psikologi Sosial. Bandung : CV. Diponegoro

[14] Pamungkas, Sigid. 2009. Perihal Pemilu, Yogyakarta : Jurusan Ilmu Pemerintahan, Fisipol UGM,

[15] Pickering, Peg. 2001.Kiat-kiat Menangani Konflik. Jakarta : Penerbit Erlangga

[16] Rachman, Maman. 1999.Strategi dan Langkah-Langkah Penelitian. Semarang :IKIP

[17] Rauf, Maswadi. 2000. Konsensus Politik Sebuah Penjajagan Teoritis.Direktorat Jenderal Pendidikan Tinggi, Departemen Pendidikan Nasional

[18] Ritzer George, 2003. Teori Sosiologi Modern. Kencana Prenada Media grouf, Jakarta

[19] Soekanto, Soerjono. 1990. Sosiologi Sebagai Suatu Pengantar. Rajawali Press. Jakarta

[20] Subakti, Ramlan, 1999, Memahami Ilmu Politik, PT. Gramedia Widiasarana Indonesia,

[21] JSP Jurnal Universitas Gadjah Mada.

[22] Riesfandhy, A, 2013, Pilkada dan Konflik, 